American Journal of Applied Sciences 7 (8): 1087-1092, 2010

ISSN 1546-9239

(C) 2010 Science Publications

\title{
Work-Related Musculoskeletal Disorders among Workers' Performing Manual Material Handling Work in an Automotive Manufacturing Company
}

\author{
Baba Md. Deros, Dian Darina Indah Daruis, Ahmad Rasdan Ismail, \\ Nurfarhana Abdullah Sawal and Jaharah A. Ghani \\ Department of Mechanical and Materials Engineering, \\ Faculty of Engineering and Built Environment, \\ University Kebangsaan Malaysia, UKM, Bangi, 43600 Selangor, Malaysia
}

\begin{abstract}
Problem statement: The study investigated the prevalence of Musculoskeletal Disorders (MSD) among workers who perform the Manual Material Handling (MMH) task in an automotive manufacturing plant in Malaysia. A cross sectional study was carried out among the workers in an automotive manufacturing plant. Approach: Respondents were selected through random sampling. Then, a Body Parts Symptoms Survey (BPSS) data sheets were given to the workers to obtain the prevalence of MSD among them. Later, a few workers were selected based on the In-House Clinic (IHC) visitations data for interviews. Results: Five hundreds workers showed that the highest prevalence of MSD was Low Back Pain (LBP). It was found from interviews of 17 workers who had 3 or more visitation times to the IHC that the main reason of the ergonomic risk comes from the task that they perform. It was found that the highest prevalence of MSD was lower back pain, followed by pain at feet/ankle and pain at upper back regions. Almost one third of the study populations claimed to feel uncomfortable to their upper back and lower back. Conclusion: It was concluded that the back pain the workers are experiencing may be a result of their ignorance in the correct and ergonomic techniques in materials handling.
\end{abstract}

Key words: Automotive, back pain, manual material handling, musculoskeletal disorders, prevalence

\section{INTRODUCTION}

Any job that involves heavy labor or Manual Material Handling (MMH) may be in a high-risk category. $\mathrm{MMH}$ entails lifting, but also includes climbing, pushing, pulling and pivoting, all of which pose the risk of injury to the back. The term musculoskeletal disorder refers to conditions that involve the nerves, tendons, muscles and supporting structures of the body (Bernard, 1997). Ranging from back strains to carpal tunnel syndrome, it is common for employers to find MSD accounting for $40 \%$ or more of their injury cases and $60 \%$ of their workers compensation costs (Adams, 2005). MSD are always being associated with MMH.

Most data concerning back pain are related to developed countries and information about back pain in developing and low-income countries are still lacking (Ghaffari et al., 2006). In Malaysia, the awareness of back pain due to study is still at a budding stage. The issue is considered new among the workers in Malaysia compared to other developed countries and it is still being promoted by the professionals especially the Occupational Safety and Health (OSH) practitioners to enhance the awareness level of all Malaysians. Besides affecting the workers health, back pain and MSD can also lower productivity. As according to Punnet and Wegman (2004), back pain is associated with substantial financial cost and loss of quality of life.

Study of Low Back Pain (LBP) among Iranian industrial workers by Ghaffari et al. (2006) found that the 1-year prevalence of self-reported LBP in the Iranian industrial population was $21 \%$. The prevalence rate of absence due to LBP was $5 \%$ per annum. The multiple logistic regression models indicated that the following remained as risk indicators for LBP in the previous 12 months: increasing age, no regular exercise, heavy lifting, repetitive study and monotonous study.

A cross-sectional study was conducted by Bernard (1997) to assess the association of upper extremity MSD and work-related factors among employees using

Corresponding Author: Baba Md. Deros, Department of Mechanical and Materials Engineering,

Faculty of Engineering and Built Environment, University Kebangsaan Malaysia, UKM, Bangi,

43600 Selangor, Malaysia 
video display terminals at a large metropolitan newspaper factory. The study included 1050 randomly selected workers from four departments. The workers were asked to complete questionnaires on symptoms, job tasks and psychosocial and study organization conditions. MSD of the upper extremities were defined by frequency, duration and intensity of symptoms not attributable to acute injury. The results suggest a high prevalence of MSD of the upper extremities among newspaper factory employees and they provide additional evidence that increased work load, time pressure and greater hours of computer use are related to the occurrence of work-related MSD among these workers, particularly for disorders in the hand or wrist area.

According to year 2007 in-house report of an automotive manufacturing company in Malaysia, the total number of workers suffering the back pain had increased from the year 2005 until 2006. A total of 954 cases of back pain were reported by the in-house clinic throughout the year. From the total number of cases reported, 783 workers had been involved with this back pain illness, which means that some of these workers had visited the in-house clinic for more than one time due to backache.

Hence, the current study was carried out to confirm the above claims from the automotive manufacturing company itself. The current study is to determine the prevalence of MSD among workers who perform the MMH before any ergonomics intervention can be introduced into the company being studied and at the same time to determine the ergonomics risk of $\mathrm{MMH}$ at the workstation of workers with back pain.

\section{MATERIALS AND METHODS}

The study was conducted in an automotive manufacturing company in Malaysia. Respondents were production operators from various sections in the production plant, such as from the Press Section, Body Section, Paint Section, Assembly Section, Casting Section, Machining Section, Engine Section and other support departments. The sample size for this study was $15 \%$ from the total production operators who worked in the same shift. Fifteen percent was thought to be enough as to represent the total number of production workers in the company which is around 6000 people. There are approximately 3000 operators in each shift. The shift rotates every week where the day shift workers for the week will be working in the night shift the week after and vice versa.

Therefore, for the purpose of this study, only about 500 workers were involved. However, for the precaution in case of any missing data, more than $10 \%$ from the calculated figures of the sample size were added. More than 500 workers were given out the questionnaire. Data were collected using three approaches through the Body Parts Symptoms Survey (BPSS), self-reported questionnaire for workstations conditions and oral interview.

The survey of comfort level to all body parts is crucial in an ergonomics assessment. It is a standard and systematic way of identifying ergonomic risk (Zavitz, 2008). For this study, BPSS was used to determine which body part is exposed to the risk from the study especially when dealing with MMH task. As shown in Fig. 1, twelve body parts were identified to be evaluated by the workers to determine the comfort level that they feel. The survey used Likert-Scale method where the comfort levels were numbered from $1-5$, the higher number means that the more uncomfortable they felt at that certain part of the body. The questionnaires had been pre-tested in order to check the reliability and validity of the questions. Results from the pre-test enabled the real test to be carried out, however with some changes to certain words that were very technical to layman language as a result from focus group discussion. Random sampling method have been applied, where the authors randomly select the subjects and gave them the BPSS sheet where they need to circle the comfort level they feel at each of the body parts.

A cross-reference was carried out through the InHouse Clinic (IHC) reports of visitations due to back pain. For workers who had visited three times or more to the clinic for back pain, they were selected to fill in the self-reported questionnaire to assess their workstation conditions in terms of ergonomics. This was to answer the second aim of this study.

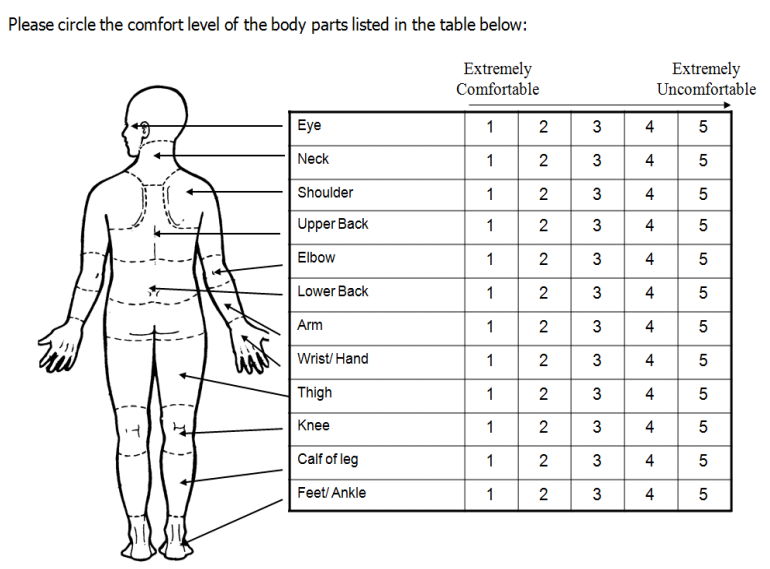

Fig. 1: Body parts symptoms survey sheet 
The self-assessment by the worker involved two parts (Part A and B) with sixteen questions. Part A was about the worker's background which was to determine the current health status, previous injuries or accidents, hobbies, lifestyles and previous job. While in Part B, the questions were more focused on the current workstation that they are in; the condition, the environmental factors and also the human factors.

Interview sessions were conducted for the reason that there might be some misunderstanding of the questions in the questionnaire form. It was also done to ensure the reliability of the data collected, so that what was answered in the survey questionnaire was the same as found from the interview.

\section{RESULTS}

A total of 525 workers were involved in this study. From the total of respondents, only 473 workers $(90.1 \%)$ answered the working shift column, while 496 of the overall respondents $(94.5 \%)$ answered the department column. There were almost similar percentages between respondents from Shift A and Shift B, with only eleven workers difference. The study populations were from Shift A workers with $39.7 \%$ (188 workers), followed by Shift B with $37.4 \%$ (177 workers). The total of Normal Shift workers who were involved in this study was 108 , which contributed to $22.8 \%$ of the study population.

The BPSS forms were distributed at the resting areas and at the canteen. These locations were chosen so that workers were minimally disturbed during their working hours. Most of the subjects participated in the study were from the Paint Section (26.4\%). The reason might be because the section itself comprises of two main buildings of the plant (car body paint building and bumper paint building). The second highest percentage of the study samples were from the Body Section $(12.9 \%)$, where their main task was to attach the cast body parts together and welds them to make a car body. The rest are from; engine $12.5 \%$, logistics $10.5 \%$, repair and accessory $8.3 \%$, casting $7.1 \%$, quality control $6.9 \%$, R\&D 5.2\%, maintenance $3.6 \%$, assembly $3.2 \%$, machining $0.2 \%$ and others $4 \%$.

Table 1 showed the trend of MSD among the workers in the plant. Low back pain showed the highest prevalence on the 'very uncomfortable' column, with 122 out of 500 workers $(24 \%)$ claimed to feel very uncomfortable to their lower back. The trend followed by feet/ankle and upper back with $20 \%$ (104 workers) and $19 \%$ (97 workers) respectively. In addition to that, a similar MSD trend was shown under the 'extremely uncomfortable' column, where $8 \%$ of 505 workers claimed to feel it at their lower back. Meanwhile, $6 \%$ feel extremely uncomfortable at their feet/ankle and $4 \%$ to their upper back.

Table 2 showed the prevalence of back pain among the workers according to their working section. The first three columns in the BPSS were considered as 'comfortable', including the middle column which is 'neutral'. The last 2 columns were considered as 'uncomfortable'.

Table 3 showed the workers' background on their knowledge of ergonomics and the back pain they suffered. Thirteen out of 17 workers did not know about ergonomics. All of them had never heard of the word ergonomics. Table 3 also lists out the details of the workers' hobbies and lifestyle.

Workers' perception on the workstation conditions were detailed in Table 4. The assessment of tasks performed by the workers who were having back pain is shown in Table 5.

Table 1: Musculoskeletal Disorders (MSD) trend

\begin{tabular}{llllll}
\hline Body part & EC $(\%)$ & VC $(\%)$ & Nt $(\%)$ & VU $(\%)$ & EU $(\%)$ \\
\hline Eye & $130(26.0)$ & $166(33.2)$ & $140(28.0)$ & $52(10.4)$ & $12(2.4)$ \\
Neck & $87(17.4)$ & $170(34.0)$ & $159(31.8)$ & $76(15.2)$ & $8(1.6)$ \\
Shoulder & $67(13.4)$ & $157(31.4)$ & $189(37.8)$ & $75(15.0)$ & $12(2.4)$ \\
Upper back & $52(10.4)$ & $137(27.4)$ & $194(38.8)$ & $97(19.4)$ & $20(4.0)$ \\
Elbow & $109(21.8)$ & $173(34.6)$ & $156(31.2)$ & $50(10.0)$ & $12(2.4)$ \\
Lower back & $48(9.6)$ & $110(22.0)$ & $179(35.8)$ & $122(24.4)$ & $41(8.2)$ \\
Arm & $95(19.0)$ & $163(32.6)$ & $169(33.8)$ & $65(13.0)$ & $8(1.6)$ \\
Hand wrist & $107(21.4)$ & $174(34.8)$ & $142(28.4)$ & $60(12.0)$ & $17(3.4)$ \\
Thigh & $91(18.2)$ & $156(31.2)$ & $187(37.4)$ & $58(11.6)$ & $8(1.6)$ \\
Knee & $64(12.8)$ & $157(31.4)$ & $166(33.2)$ & $88(17.6)$ & $25(5.0)$ \\
Calf of leg & $78(15.6)$ & $150(30.0)$ & $188(37.6)$ & $72(14.4)$ & $12(2.4)$ \\
Feet/ankle & $78(15.6)$ & $139(27.8)$ & $146(29.2)$ & $104(20.8)$ & $33(6.6)$ \\
\hline EC: Extremely & Comfortable; VC: Very Comfortable; Nt: Neutral; VU: Very Uncomfortable; EU: Extremely Uncomfortable &
\end{tabular}


Am. J. Applied Sci., 7 (8): 1087-1092, 2010

Table 2: Prevalence of back pain

\begin{tabular}{|c|c|c|c|c|c|c|}
\hline \multirow[b]{3}{*}{ Department/section } & \multicolumn{6}{|l|}{ Body part } \\
\hline & \multicolumn{3}{|l|}{ Upper back } & \multicolumn{3}{|l|}{ Lower back } \\
\hline & $\mathrm{C}(\%)$ & $\mathrm{UC}(\%)$ & $\mathrm{N}$ & $\mathrm{C}(\%)$ & $\mathrm{UC}(\%)$ & $\mathrm{N}$ \\
\hline Body & $41(67.2)$ & $20(32.8)$ & 61 & $42(71.2)$ & $17(28.8)$ & 59 \\
\hline Paint & $110(85.3)$ & 19 (14.7) & 129 & 95 (74.2) & $33(25.8)$ & 128 \\
\hline Assembly & $13(81.3)$ & $3(18.8)$ & 16 & $10(62.5)$ & $6(37.5)$ & 16 \\
\hline Casting & $25(71.4)$ & $10(28.6)$ & 35 & $21(61.8)$ & $13(38.2)$ & 34 \\
\hline Machining & $1(100)$ & - & 1 & $1(100)$ & - & 1 \\
\hline Engine & $41(69.5)$ & $18(30.5)$ & 59 & $36(61.0)$ & $23(39.0)$ & 59 \\
\hline Logistics & 39 (76.5) & $12(23.5)$ & 51 & $36(70.6)$ & $15(29.4)$ & 51 \\
\hline Maintenance & $11(61.1)$ & $7(38.9)$ & 18 & $10(58.8)$ & 7 (41.2) & 17 \\
\hline Quality control & $28(82.4)$ & $6(17.6)$ & 34 & $22(66.7)$ & $11(33.3)$ & 33 \\
\hline Repair and accessory & $26(66.7)$ & $13(33.3)$ & 39 & $22(56.4)$ & 17 (43.6) & 39 \\
\hline $\mathrm{R}$ and $\mathrm{D}$ & $22(91.7)$ & $2(8.3)$ & 24 & $16(66.7)$ & $8(33.3)$ & 24 \\
\hline Others & $5(71.4)$ & $2(28.6)$ & 7 & $6(54.5)$ & $5(45.5)$ & 11 \\
\hline Overall & $383(76.6)$ & $117(23.4)$ & 500 & $336(67.2)$ & $163(32.6)$ & 500 \\
\hline
\end{tabular}

C: Comfortable; UC: Uncomfortable

Table 3: Worker's background

\begin{tabular}{|c|c|c|c|c|c|c|c|c|c|c|c|c|c|c|c|c|c|c|}
\hline \multirow[b]{3}{*}{ Section } & \multicolumn{6}{|c|}{ Ergonomics knowledge } & \multicolumn{6}{|c|}{ History of back pain } & \multicolumn{6}{|c|}{ Hobby } \\
\hline & \multicolumn{2}{|c|}{$\begin{array}{l}\text { Know } \\
\text { Ergonomics }\end{array}$} & \multicolumn{2}{|c|}{$\begin{array}{l}\text { Attended } \\
\text { Ergonomics } \\
\text { class }\end{array}$} & \multicolumn{2}{|c|}{$\begin{array}{l}\text { Back pain } \\
\text { limits } \\
\text { routine work }\end{array}$} & \multicolumn{2}{|c|}{$\begin{array}{l}\text { Surgery to the } \\
\text { back }\end{array}$} & \multicolumn{2}{|c|}{$\begin{array}{l}\text { Involved } \\
\text { previous } \\
\text { accident }\end{array}$} & \multicolumn{2}{|c|}{$\begin{array}{l}\text { Prolonged } \\
\text { ache until } \\
\text { present }\end{array}$} & \multicolumn{2}{|c|}{$\begin{array}{l}\text { Same problem } \\
\text { in previous job }\end{array}$} & \multicolumn{2}{|c|}{$\begin{array}{l}\text { Planting/ } \\
\text { gardening }\end{array}$} & \multicolumn{2}{|l|}{ Sports } \\
\hline & $\begin{array}{l}\text { Yes } \\
(\%)\end{array}$ & $\begin{array}{l}\text { No } \\
(\%)\end{array}$ & $\begin{array}{l}\text { Yes } \\
(\%)\end{array}$ & $\begin{array}{l}\text { No } \\
(\%)\end{array}$ & $\begin{array}{l}\text { Yes } \\
(\%)\end{array}$ & $\begin{array}{l}\text { No } \\
(\%)\end{array}$ & $\begin{array}{l}\text { Yes } \\
(\%)\end{array}$ & $\begin{array}{l}\text { No } \\
(\%)\end{array}$ & $\begin{array}{l}\text { Yes } \\
(\%)\end{array}$ & $\begin{array}{l}\text { No } \\
(\%)\end{array}$ & $\begin{array}{l}\text { Yes } \\
(\%)\end{array}$ & $\begin{array}{l}\text { No } \\
(\%)\end{array}$ & $\begin{array}{l}\text { Yes } \\
(\%)\end{array}$ & $\begin{array}{l}\text { No } \\
(\%)\end{array}$ & $\begin{array}{l}\text { Yes } \\
(\%)\end{array}$ & $\begin{array}{l}\text { No } \\
(\%)\end{array}$ & $\begin{array}{l}\text { Yes } \\
(\%)\end{array}$ & $\begin{array}{l}\text { No } \\
(\%)\end{array}$ \\
\hline Body & $1(25)$ & $7(53.8)$ & - & $8(50)$ & $4(57.1)$ & $4(40)$ & $1(100)$ & $7(43.8)$ & $5(55.6)$ & $3(37.5)$ & $2(50)$ & $6(46.2)$ & $3(50)$ & $5(45.5)$ & $1(50)$ & $7(46.7)$ & $3(30)$ & $5(71.4)$ \\
\hline Assembly & - & $4(30.8)$ & - & $4(25)$ & $1(14.3)$ & $3(30)$ & - & $4(25)$ & $1(11.1)$ & $3(37.5)$ & $1(25)$ & $3(23.1)$ & - & $4(36.4)$ & - & $4(26.7)$ & $3(30)$ & $1(14.3)$ \\
\hline Engine & $2(50)$ & $2(15.4)$ & $1(100)$ & $3(18.8)$ & $1(14.3)$ & $3(30)$ & - & $4(25)$ & $3(33.3)$ & $1(12.5)$ & $1(25)$ & $3(23.1)$ & $3(50)$ & $1(9.1)$ & - & $4(26.7)$ & $3(30)$ & $1(14.3)$ \\
\hline Machining & $1(25)$ & - & - & $1(6.3)$ & $1(14.3)$ & - & - & $1(6.3)$ & - & $1(12.5)$ & - & $1(7.7)$ & - & $1(9.1)$ & $1(50)$ & - & $1(10)$ & - \\
\hline $\mathrm{N}$ & 4 & 13 & 1 & 16 & 7 & 10 & 1 & 16 & 9 & 8 & 4 & 13 & 6 & 11 & 2 & 15 & 10 & 7 \\
\hline
\end{tabular}

Table 4: Worker's background (cont'd)

\begin{tabular}{|c|c|c|c|c|c|c|c|c|}
\hline \multirow[b]{3}{*}{ Section } & \multicolumn{8}{|c|}{ Lifestyle } \\
\hline & \multicolumn{2}{|c|}{ Frequent exercise } & \multicolumn{2}{|c|}{ Maintain good posture } & \multicolumn{2}{|c|}{ Taking balance diet } & \multicolumn{2}{|c|}{ Enough rest and sleep } \\
\hline & $\begin{array}{l}\text { Yes } \\
(\%) \\
\end{array}$ & $\begin{array}{l}\text { No } \\
(\%)\end{array}$ & $\begin{array}{l}\text { Yes } \\
(\%) \\
\end{array}$ & $\begin{array}{l}\text { No } \\
(\%)\end{array}$ & $\begin{array}{l}\text { Yes } \\
(\%) \\
\end{array}$ & $\begin{array}{l}\text { No } \\
(\%)\end{array}$ & $\begin{array}{l}\text { Yes } \\
(\%) \\
\end{array}$ & $\begin{array}{l}\text { No } \\
(\%)\end{array}$ \\
\hline Body & $3(27.3)$ & $5(83.3)$ & $3(33.3)$ & $5(62.5)$ & $4(40)$ & $4(57.1)$ & $5(50)$ & $3(42.9)$ \\
\hline Assembly & $3(27.3)$ & $1(16.7)$ & $2(22.2)$ & $3(25)$ & $2(20)$ & $2(28.6)$ & $1(10)$ & $3(42.9)$ \\
\hline Engine & $4(36.4)$ & - & $3(33.3)$ & $2(12.5)$ & $3(30)$ & $1(14.3)$ & $4(40)$ & - \\
\hline Machining & $1(9.1)$ & - & $1(11.1)$ & - & $1(10)$ & - & - & $1(14.3)$ \\
\hline $\mathrm{N}$ & 11 & 6 & 9 & 8 & 10 & 7 & 10 & 7 \\
\hline
\end{tabular}

Table 5: Workstation self-assessment-workstation conditions

\begin{tabular}{|c|c|c|c|c|c|c|c|c|c|c|c|c|c|c|c|c|}
\hline \multirow[b]{3}{*}{ Section } & \multirow{2}{*}{\multicolumn{2}{|c|}{ Condition }} & \multirow{2}{*}{\multicolumn{2}{|c|}{ Space is small }} & \multirow{2}{*}{\multicolumn{2}{|c|}{$\begin{array}{l}\text { Restricted space for } \\
\text { movement }\end{array}$}} & \multirow{2}{*}{\multicolumn{2}{|c|}{$\begin{array}{l}\text { Insufficient } \\
\text { height }\end{array}$}} & \multicolumn{8}{|c|}{ Working environment } \\
\hline & & & & & & & & & \multicolumn{2}{|c|}{ Ventilation } & \multicolumn{2}{|c|}{ Lighting } & \multicolumn{2}{|l|}{ Noise } & \multicolumn{2}{|c|}{ Temperature } \\
\hline & $\begin{array}{l}\mathrm{OK} \\
(\%) \\
\end{array}$ & $\begin{array}{l}\mathrm{NG} \\
(\%) \\
\end{array}$ & $\begin{array}{l}\text { Yes } \\
(\%)\end{array}$ & $\begin{array}{l}\text { No } \\
(\%)\end{array}$ & $\begin{array}{l}\text { Yes } \\
(\%)\end{array}$ & $\begin{array}{l}\text { No } \\
(\%)\end{array}$ & $\begin{array}{l}\text { Yes } \\
(\%) \\
\end{array}$ & $\begin{array}{l}\text { No } \\
(\%)\end{array}$ & $\begin{array}{l}\text { OK } \\
(\%)\end{array}$ & $\begin{array}{l}\mathrm{NG} \\
(\%)\end{array}$ & $\begin{array}{l}\text { OK } \\
(\%)\end{array}$ & $\begin{array}{l}\mathrm{NG} \\
(\%) \\
\end{array}$ & $\begin{array}{l}\text { OK } \\
(\%)\end{array}$ & $\begin{array}{l}\mathrm{NG} \\
(\%) \\
\end{array}$ & $\begin{array}{l}\text { OK } \\
(\%) \\
\end{array}$ & $\begin{array}{l}\mathrm{NG} \\
(\%) \\
\end{array}$ \\
\hline Body & $6(46.2)$ & $2(50)$ & $3(50)$ & $5(45.5)$ & $1(33.3)$ & $7(50)$ & $4(66.7)$ & $4(36.4)$ & $6(50)$ & $2(40)$ & $8(50)$ & - & $3(33.3)$ & $5(62.5)$ & $6(50)$ & $2(40)$ \\
\hline Assembly & $3(23.1)$ & $1(25)$ & - & $4(36.5)$ & - & $4(28.6)$ & $1(16.7)$ & $3(27.3)$ & $3(25)$ & $1(20)$ & $4(25)$ & - & $2(22.2)$ & $2(25)$ & $3(25)$ & $1(20)$ \\
\hline Engine & $4(30.8)$ & - & $2(33.3)$ & $2(18.2)$ & $2(66.7)$ & 2(14.3) & $1(16.7)$ & $3(27.3)$ & $3(25)$ & $1(20)$ & $3(18.8)$ & $1(100)$ & $4(44.4)$ & - & $3(25)$ & $1(20)$ \\
\hline Machining & - & $1(25)$ & $1(16.7)$ & - & - & $1(7.1)$ & - & $1(9.1)$ & - & $1(20)$ & $1(6.3)$ & & - & $1(12.5)$ & - & $1(20)$ \\
\hline $\mathrm{N}$ & 13 & 4 & 6 & 11 & 3 & 14 & 6 & 11 & 12 & 5 & 16 & 1 & 9 & 8 & 12 & 5 \\
\hline
\end{tabular}


Am. J. Applied Sci., 7 (8): 1087-1092, 2010

Table 6: Workstation self-assessment-task performed

\begin{tabular}{|c|c|c|c|c|c|c|c|c|c|c|c|c|c|c|}
\hline \multirow[b]{2}{*}{ Section } & \multicolumn{2}{|c|}{ Lifting (\%) } & \multicolumn{2}{|c|}{ Pushing (\%) } & \multicolumn{2}{|c|}{ Pulling (\%) } & \multicolumn{2}{|c|}{ Trunk bending (\%) } & \multicolumn{2}{|c|}{ Head lifting $(\%)$} & \multicolumn{2}{|c|}{ Twisting (\%) } & \multicolumn{2}{|c|}{ Extended reach $(\%)$} \\
\hline & Yes & No & Yes & No & Yes & No & Yes & No & Yes & No & Yes & No & Yes & No \\
\hline Body & $7(46.7)$ & $1(50)$ & $6(50)$ & $2(40)$ & $7(58.3)$ & $1(20)$ & $7(50)$ & $1(33.3)$ & $3(37.5)$ & $5(55.6)$ & $7(50)$ & $1(33.3)$ & $6(60)$ & $2(28.6)$ \\
\hline Assembly & $3(20)$ & $1(50)$ & $2(16.7)$ & $2(40)$ & $2(16.7)$ & $2(40)$ & $3(21.4)$ & $1(33.3)$ & $2(25)$ & $2(22.2)$ & $2(14.3)$ & $2(66.7)$ & $2(20)$ & $2(28.6)$ \\
\hline Engine & $4(26.7)$ & - & $3(25)$ & $1(20)$ & $2(16.7)$ & $2(40)$ & $3(21.4)$ & $1(33.3)$ & $2(25)$ & $2(22.2)$ & $4(28.6)$ & - & $1(10)$ & $3(42.9)$ \\
\hline Machining & $1(6.7)$ & - & $1(8.3)$ & - & $1(8.3)$ & - & $1(7.1)$ & - & $1(12.5)$ & - & $1(7.1)$ & - & $1(10)$ & - \\
\hline \multirow[t]{3}{*}{$\mathrm{N}$} & 15 & 2 & 12 & 5 & 12 & 5 & 14 & 3 & 8 & 9 & & 3 & & 7 \\
\hline & \multicolumn{2}{|c|}{ Excessive force $(\%)$} & \multicolumn{2}{|c|}{ Foot lifting (\%) } & \multicolumn{2}{|c|}{ Excessive motion (\%) } & \multicolumn{2}{|c|}{ Repetitive work (\%) } & \multicolumn{2}{|c|}{ Static load (\%) } & \multicolumn{2}{|c|}{ Static pressure $(\%)$} & \multicolumn{2}{|c|}{ Vibration (\%) } \\
\hline & Yes & No & Yes & No & Yes & No & Yes & No & Yes & No & Yes & No & Yes & No \\
\hline Body & $5(55.6)$ & $3(37.5)$ & $3(50)$ & $5(45.5)$ & $4(44.4)$ & $4(50)$ & $7(53.8)$ & $1(25)$ & $5(71.4)$ & $3(30)$ & $6(50)$ & $2(40)$ & $4(50)$ & $4(44.4)$ \\
\hline Assembly & $1(11.1)$ & $3(37.5)$ & $2(33.3)$ & $2(18.2)$ & $2(22.2)$ & $2(25)$ & $2(15.4)$ & $2(50)$ & $2(28.6)$ & $2(20)$ & $1(8.3)$ & $3(60)$ & $3(37.5)$ & $1(11.1)$ \\
\hline Engine & $3(33.3)$ & $1(12.5)$ & $1(16.7)$ & $3(27.3)$ & $2(22.2)$ & $2(25)$ & $4(30.8)$ & - & - & $4(40)$ & $4(33.3)$ & - & - & 4 (44.4) \\
\hline Machining & - & $1(12.5)$ & - & $1(9.1)$ & $1(11.1)$ & - & - & $1(25)$ & - & $1(10)$ & $1(8.3)$ & - & $1(12.5)$ & - \\
\hline $\mathrm{N}$ & 9 & 8 & 6 & 11 & 9 & 8 & 13 & 4 & 7 & 10 & 12 & 5 & 8 & 9 \\
\hline
\end{tabular}

\section{DISCUSSION}

Trend of MSD: Departments or sections with more than $10 \%$ workers are the Paint, Body, Engine and Logistics. Among these four, Body and Engine sections involved with demanding MMH works such as lifting, moving and handling heavy mostly metal parts. It is expected that the prevalence of MSD for those workers were back and feet discomforts or pains (Table 1). Morken et al. (2003) suggested that MSD especially LBP have high prevalence rate especially among the blue-collar workers, to the point that it can be used to predict sickness absence.

Furthermore, the production volume was high most of the time. Therefore, with the short tact time work plan, it was observed that there were high frequencies of carrying out similar tasks. It might be the reason to the pains experienced at lower and upper back. As for the feet and ankle, it might be due to the fact that most tasks were standing position tasks. The workers might feel exhausted for the prolonged standing position.

Prevalence of back pain: As shown in Table 2, the highest prevalence among the main sections for upper back pain was found among Body section (32.8\%) and Engine section $(30.5 \%)$ workers. As for the support group, Repair and Accessory section noted the highest percentage of upper back pain with thirteen out of 39 workers, $33.3 \%$ have an uncomfortable feeling to their upper back. Meanwhile, for the uncomfortable feeling to the lower back, the top three highest prevalence among the main sections were found at Engine section (39.0\%), followed by Casting section $(38.2 \%)$ and Assembly section (37.5\%). This again is expected since all the materials were medium to large sized metal parts of the car body and engine. Manual handling of those parts require much force from the workers. Wrong postures and techniques of handling the parts will definitely cause discomfort and pains. A more detail investigations to quantify the degree of risk by body part need to be carried out in the next step of risk assessment such as identifying how many degrees the back bend or how much force exerted.

Ergonomic risks: It could be presumed that the back pain that the workers' are experiencing may be a result of not knowing the correct and ergonomic techniques and practices in MMH. As shown in Table 3, 40\% of the workers thought that back pain had limited their routine work, nevertheless only four of them still experiencing back pain until present. Quite alarming is that nine of them had previously involved in accidents while one had a surgery to the back. Six workers claimed to have suffered the back pain since their previous job and the back pain worsen at their current workstations as a result of MMH. From this health background result, it is thought that it does not represent the ergonomic risks as a result of task that the workers of the whole plant perform. Furthermore, the number of workers that have been visiting the in-house clinic for three times and more is too small to be representative for the whole plant. The results also showed that the workers are practicing good lifestyle with frequent exercise, maintaining good posture, taking balance diet and get enough rest and sleep. However, smoking habit is another important point to be investigate in any prevalence of musculoskeletal-disorder studies especially if it's involving blue-collar workers (Inoue and Harada, 2002). This matter is not discussed here and will be critically analyzed in future study.

Overall judgment of the workstation conditions was good. Most of the workers answered the condition of the workstation was acceptable, the space is not small and did not restrict the workers for movement and the height was also satisfactory (Table 4). About the working environment, apart from ventilation, lighting and temperature conditions, half of the workers $(50 \%)$ agreed that their working environment was noisy due to 
the machines and tools used to perform the work. Nearly most of the task stated including lifting, pushing, pulling, trunk bending, twisting and extended reach (Table 5). From the oral interview, the workers claimed that those tasks to be the main factor of back pain. Their claims as shown in Table 6 correlated well with the findings showed in Table 1 and 2 . In addition to the above issues, workers also feel that the back pain they had suffered is due to the excessive force and motions used during work. Thirteen workers performed the same task over and over again, repetitively. Repetitive work, although in sitting position has been shown to be the cause of MSD and LBP (Ghaffari et al., 2006). Only seven workers worked in standing positions for long durations. Half of the workers perceive vibration effect when handling the job; this may due to the fact that workers from Body and Assembly sections used an impact gun which is vibrated to perform their jobs.

\section{CONCLUSION}

A total of 500 workers were involved in the BPSS to achieve the first objective of the study, which is to determine the trend of musculoskeletal disorders and the prevalence of back pain among workers who perform the Manual Material Handling (MMH) study. It was found that the highest prevalence of MSD was lower back pain, followed by pain at feet/ankle and pain at upper back regions. Almost one third of the study populations claimed to feel uncomfortable to their upper back and lower back. The workers claimed that the back pain is due to the excessive force and motions used during study. It was presumed that the back pain the workers are experiencing may be a result of their ignorance in the correct and ergonomic techniques in materials handling.

\section{ACKNOWLEDGMENT}

The researchers would like to acknowledge the financial contributions both from Ministry Of Science, Technology and Innovation and Ministry Of Higher Education for their grants.

\section{REFERENCES}

Adams, P.S., 2005. Selecting ergonomic analysis tools. Proceeding of the ASSE Professional Development Conference and Exposition, June 12-15, American Society of Safety Engineers, New Orleans, Louisiana, $\quad$ pp: 1-13. http://www.onepetro.org/mslib/servlet/onepetropre view?id=ASSE-05$521 \&$ soc $=$ ASSE $\&$ spe AppNameCookie $=$ ONEPET $\mathrm{RO}$

Bernard, B.P., 1997. Musculoskeletal disorders and workplace factors: A critical review of epidemiologic evidence for work-related disorders of the neck, upper extremities and low back. National Institute for Occupational Safety and Health. http://www.cdc.gov/niosh/docs/97-141/

Ghaffari, M., A. Alipour, I. Jensen, A.A. Farshad and E. Vingard, 2006. Low back pain among Iranian industrial workers. Occup. Med., 56: 455-460. DOI: 10.1093/occmed/kq1062

Inoue, M. and N. Harada, 2002. Habitual smoking and musculoskeletal symptoms in Japanese blue-collar workers. J. Occup. Health, 44: 315-320. http://joh.med.uoeh-u.ac.jp/pdf/E44/E44_5_05.pdf

Morken, T., T. Riise, B. Moen, S.H.V. Hauge and S. Holien et al., 2003. Low back pain and widespread pain predict sickness absence among industrial workers. BMC Musculoskelet Disord., 4: 21-21. DOI: 10.1186/1471-2474-4-21

Punnet, L. and D.H. Wegman, 2004. Work-related musculoskeletal disorders: The epidemiologic evidence and the debate. J. Electromyogr. Kinesiol., 14 : 13-23. DOI: 10.1016/j.jelekin.2003.09.015

Zavitz, B., 2008. Injury prevention through ergonomic risk assessment. Priority Press. http://www.eorm.com/ezine/pp13/on_ergo2.asp 